\title{
The effects of social relationships during childhood on mitigating the development of the vulgar personality
}

Tsuyoshi Hatori (Faculty of Collaborative Regional Innovation, Ehime University, hatori@cee.ehime-u.ac.jp)

Satoshi Fujii (Graduate School of Engineering, Kyoto University, fujii@trans.kuciv.kyoto-u.ac.jp)

Yoshihiro Komatsu (Research \& Development Center of JR East Group)

幼少期における社会的関係が大衆性の発達を緩和する効果に関する研究

羽鳥 剛史（愛媛大学 社会共創学部）

藤井 聡 (京都大学大学院工学研究科)

小松 佳弘（JR 東日本研究開発センター）

\section{要約}

先行研究（Hatori et al., 2016）において、オルテガが『大衆の反逆』の中で論じている人々の大衆性が社会的ジレンマ状 況において非協力行動を促進することが指摘されている。この結果を受けて、本研究は、幼少期の家庭や地域コミュニティ における社会的関係が大衆性の発達を緩和寸る効果について探索的に検討することを目的とした。この目的の下、全国 の一般成人 1000 名を対象とした調査を実施した。その結果、幼少期における社会的関係と大衆性を構成する自己閉塞性 との間に有意な関連性が確認された。具体的には、家庭内のしつけや地域コミュニティの連帯が自己閉塞性の発達を緩 和することが示された。さらに、幼少期における社会的関係は、自己閉塞性への影響を介して、大衆性を構成するもう 1 つの因子である傲慢性の発達を抑制するという間接的な効果を持つ可能性も示唆された。

\section{Key words}

Vulgarity Scale, personality development, the masses, social relationships, social dilemmas

\section{Introduction}

Many problems in modern society, including overpopulation, environmental degradation, pollution, traffic jams, and recent increases in atmospheric carbon dioxide $\left(\mathrm{CO}_{2}\right)$, can be regarded as instances of social dilemmas whereby the pursuit of individual self-interest is more powerful than the broader collective interest. According to Dawes (1980), social dilemmas are characterized by two properties: the payoff to each individual is higher when acting in his or her own interest (called defection) than when acting in the interest of the collective (called cooperation), irrespective of the actions of other members; and all individuals receive a lower payoff if all defect than if all cooperate. In these situations, acting in one's self-interest appears alluring to each person, even though all people can benefit by acting in the collective interest.

Fortunately, we can find many real-world examples of people cooperating in the context of social dilemmas. For example, individuals can voluntarily save energy, buy environmentfriendly goods, visit the polls to vote, and use public transportation. Considerable evidence from laboratory experiments also indicates that many subjects are more cooperative than is assumed within the standard model of rational self-interest (e.g., Dawes \& Thaler, 1988; Ledyard, 1995). Indeed, it has been reported that more than half of available resources are allocated to benefit the group as a whole at the expense of personal welfare (see Dawes \& Thaler, 1988; Marwell \& Ames, 1979, 1980).

Unfortunately, however, we have also observed that people often do not cooperate in response to social dilemmas. For example, individuals can waste energy, throw litter in the street, abstain from voting, and use cars excessively. Some researchers have acknowledged the existence of apparent hardcore or steady defectors who defect even under conditions that encourage cooperation (Kerr \& Kaufman-Gilliland, 1994). In reviewing previous research on social dilemmas, Mlicki (1992) noted that, "Most of the results are between $11 \%$ and $50 \%$ of cooperation, which means that no matter the conditions, some cooperators, as well as some defectors, will always be found." (as cited by Kerr \& Kaufman-Gilliland, 1994, p. 526).

\subsection{Vulgarity of the mass man as a predictor of defection}

Based on the theory of the masses, which the Spanish philosopher José Ortega y Gasset developed in his book The Revolt of the Masses (1932), Hatori, Fujii, and Komatsu (2016) attempted to shed new light on the personality structure of hardcore defectors. Ortega proposed that a type of human, known as the mass man, had emerged during the modern era. Despite access to a variety of technological and political possibilities, the mass man leads a pampered life that is characterized by immorality. Although many philosophers and sociologists have offered critiques of the masses (e.g., Arendt, 1951; Fromm, 1941; Le Bon, 1947; Mannheim, 1940), Ortega's concept differed from previous notions in that it represents a psychological 
type rather than a status or a class (for reviews of Ortega's concept of the mass, see Raley, 1971; Tuttle, 1996). Indeed, Ortega repeatedly denounced the vulgar disposition of the mass man and argued that the vulgar masses destroy the ancient virtues bequeathed by their predecessors in forms such as norms, traditions, and morals.

Hatori et al. (2016) developed the Vulgarity Scale to measure the personality of the mass man as described by Ortega (1932). This scale consists of two subscales: arrogant, and selfclosed factors. The first factor is related to tendencies toward disobedience and blind faith in one's own ability while the second is associated with aversion to social relationships and a lack of reverence for traditions. Thus, the vulgar personality of the mass man can be characterized by two distinct factors, one of which involves aggressiveness and extroversion and one of which involves passivity and introversion. Hatori et al. (2016) demonstrated that the Vulgarity Scale is predictive of defection in real-life social dilemmas such as illegal bicycle parking, littering, and the destruction of landscapes. In particular, the scale predicted these behaviors over and above the predictive contributions of other related measures; i.e., value types (Schwartz, 1992) and social value orientation (Van Lange, 1999). Overall, the results of this study support the view of the mass man as a defector who causes social dilemmas.

\subsection{Social relationships and the development of vulgarity}

Given that the mass man is identified as a defector, it may become important to ask about the roots of vulgarity or the origins of the mass man. Although the development of vulgar personality which is originally conceptualized through Ortega's (1932) philosophical discussions has not been empirically examined in the field of developmental psychology, among the possible answers to this question is that the development of a vulgar disposition may depend on social relationships during early life (Kelley, 1997). For example, a person who has experienced many positive relationships with family members or neighbours may be more likely to see the world as maintained through human cooperation. As a result, such individuals may develop an open mind and trust in others, which seem incompatible with the characteristics of the mass man. On the other hand, a person who has not had sufficient experiences with such relationships may be more likely to see the world as untrustworthy. Such individuals may appear to form closed minds and distrust of others, which seems consistent with the characteristics of the mass man. Indeed, several researchers have suggested that modernization weakens family and community cohesion (e.g., Elliott \& Merrill, 1961). Given Ortega's argument (1932) that the emergence of the masses has been enhanced during the modern era, it is conceivable that this massification was accentuated by such social disorganization during that era.

The effects of experiences with social relationships on personality development have been described by previous studies.
From the perspective of interdependency theory (Kelley, 1997), Van Lange, Otten, De Bruin, and Joireman (1997) have shown that differences in social value orientation can be attributed to different patterns of social interaction in interdependence situations encountered during early childhood through to young adulthood and possibly even later in life. Furthermore, many researchers have indicated that children with cohesive families or close friendships are more likely to behave in prosocial ways (e.g., Romig \& Bakken, 1992; Schonert-Reichl, 1999). It has also been suggested that individuals raised in environments with high levels of collectivism and interdependence (e.g., homogeneous rural environments) are inclined to be more cooperative than individuals raised in environments with low levels of collectivism and interdependence (e.g., heterogeneous urban environments; see Kagen \& Knight, 1981; Madsen \& Shapira, 1970). ${ }^{(1)}$

Thus, the present exploratory study investigated the process by which the vulgarity of the mass man discussed in Ortega (1932) develops. Consistent with the findings of previous studies, a vulgar personality may also be a product of social relationships. In particular, it is possible that unsatisfactory relationships with family and community members experienced during young childhood and early adolescence may have a great impact on the development of a vulgar personality. Indeed, a vulgar disposition may be further systematically shaped by social relations throughout a lifetime. Our exploratory examination of these speculations attempted to identify relevant factors and patterns leading to the development of a vulgar disposition.

\section{Methods}

For the above purpose, the present study examined the effects of social relationships during childhood on mitigation of the development of a vulgar personality which Ortega (1932) discussed. For the dependent variable, we used the data of Vulgarity Scale which was collected in a previous survey reported in Hatori et al. (2016). For the independent variables, we used the variables regarding social experiences in childhood which were measured in the survey but were not used in the previous research by Hatori et al.

\subsection{Participants and procedures}

Data for this study were obtained from the survey on the World Wide Web, as was reported in Hatori et al. (2016). Participants were members of a panel recruited by the Japanese Internet survey company Rakuten Research. The survey was completed by 1000 participants (500 males and 500 females; $M$ age $=44.40$ years; $S D=13.3$ years) who were recruited as an approximation of the Japanese adult population in terms of age and sex. They were selected equally from various residential areas in Japan that were categorized into three broad classifications: metropolitan cities (Tokyo, Osaka, and Aichi), mediumsized cities (Sapporo, Fukuoka, and Saitama), and small-sized 
cities (Tokushima, Kagawa, Kochi, Ehime, Saga, Nagasaki, Kumamoto, Oita, Miyazaki, and Kagoshima).

Participants visited the Rakuten Research website to complete the survey, which was 50 pages in length, and were asked to answer all of the items presented on each page and then to proceed to the next page.

\subsection{Measures}

The Vulgarity Scale. To measure the vulgar personality associated with those whom Ortega (1932) called the mass man, the Vulgarity Scale developed by Hatori et al. (2016) was employed. This scale was constructed on the basis of Ortega's descriptions of the characteristics of the mass man and is composed of an arrogant factor and a self-closed factor. This measure includes 14 items (Table 1) to which participants responded using a sevenpoint scale ranging from 1 (totally disagree) to 7 (totally agree). Measurements for the two factors were constructed by averaging across the eight items for the arrogant factor and the six items for the self-closed factor after reversing the scoring where necessary. The alpha reliabilities of the two constructs were satisfactory: $\alpha=.76$ for the arrogant factor and $\alpha=.70$ for the selfclosed factor. The correlation between the two factors was .16 ( $p$ $<.001)^{(2)}$.

Table 1: The Vulgarity Scale

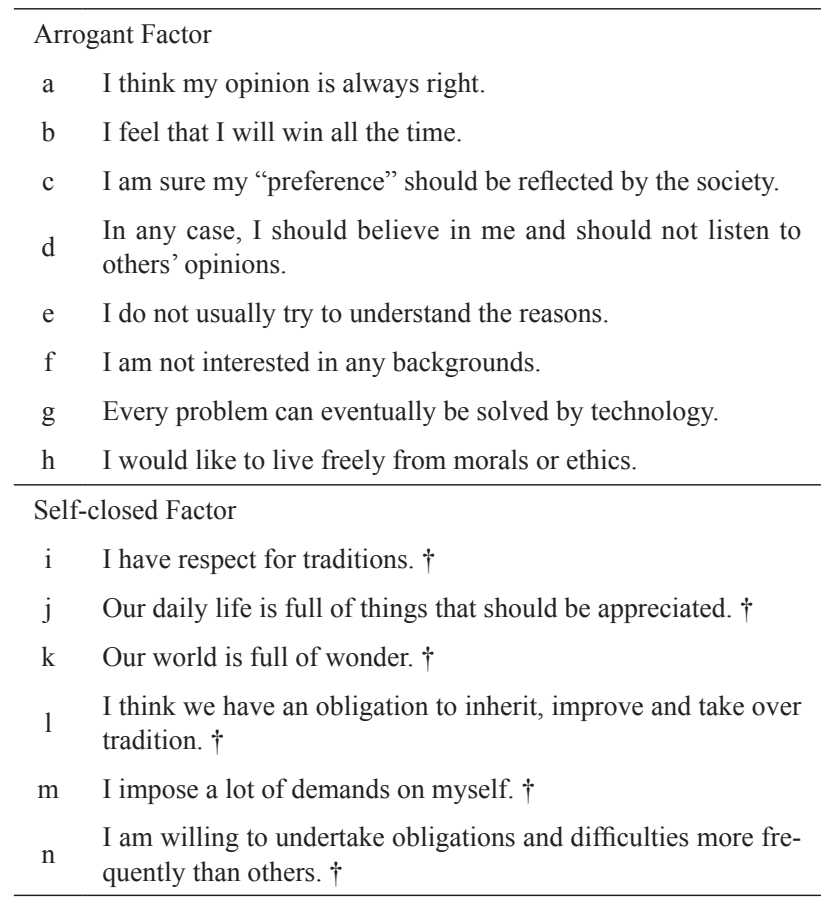

Note: $\uparrow$ Reverse-scored item

Social relationships during childhood. Measures assessing different patterns of social relation during early childhood were created in an exploratory manner. Participants were asked to respond to the items regarding social experiences in childhood shown in Table 2. The items reflect experiences and habits early in life including discipline in the home (e.g., greetings, housework), conversations among family members and neighbors, and participation in seasonal events (e.g., visiting a family tomb, regional festivals). These items were rated on a seven-point scale.

To consolidate these items into a few indicators, the 18 items were subjected to a factor analysis with promax rotation. Four factors were extracted from this analysis. The first factor had an eigenvalue of 5.31, the second factor had an eigenvalue of 1.53, the third factor had an eigenvalue of 1.37 , and the fourth factor had an eigenvalue of 1.12; these factors explained 29.50 $\%, 8.49 \%, 7.61 \%$, and $6.22 \%$ of the variance, respectively. We constructed an additive scale for each of the four factors, which consisted of all items with loadings of at least 30 on their respective factor. The alpha reliabilities for these constructs were as follows: the first factor had an $\alpha$ value of .78; the second factor had an $\alpha$ value of .70; the third factor had an $\alpha$ value of .70; and the fourth factor had an $\alpha$ value of .46. The internal consistency of the fourth factor was judged to be unacceptable. Therefore, in what follows, we examined each of the items constituting this factor on an individual basis. The remaining items, which loaded below .30 on all four factors, were also used as individual variables (see Table 2 for the results of the factor analysis). The first factor, regional solidarity, included five items concerning the degree to which an individual was associated with his or her neighbours and participated in regional events during early childhood. The second factor, family ties, included four items concerning the degree to which an individual was associated with his or her family members during early childhood. The third factor, home discipline, comprised four items concerning the degree to which an individual was disciplined at home during early childhood.

Additionally, the participants were asked to list their siblings because, as noted by Van Lange et al. (1997), the number of siblings represents a more objective measure of the degree of social interaction experienced during early childhood.

\section{Results}

\subsection{Gender, age differences, and descriptive statistics}

No significant differences were found between men and women for the two vulgarity factors $(t=-0.40$ for the arrogant factor and $t=-1.46$ for the self-closed factor). The arrogant factor was not correlated with age $(r=.02, p>.1)$ while the selfclosed factor showed a significant but low correlation with age $(r=-.08, p<.05)$. Table 3 presents the means of the two factors according to residential area; there were no significant differences among metropolitan, medium-sized, and small-sized cities for the arrogant factor $(F(2,1000)=2.92, p=.054)$ or for the self-closed factor $(F(2,1000)=0.02, p=.976)$. Comparisons by prefecture also revealed no significant differences for either the arrogant factor $(F(15,1000)=0.88, p=.591)$ or the selfclosed factor $(F(15,1000)=1.47, p=.108)$. Thus, we found 
Table 2: Factor loadings for social relationships during childhood and correlations with the Vulgarity Scale

\begin{tabular}{|c|c|c|c|c|c|c|}
\hline & \multirow{2}{*}{ Item } & \multicolumn{3}{|c|}{ Factor loadings } & \multirow{2}{*}{$\begin{array}{c}\text { Arrogant } \\
r\end{array}$} & \multirow{2}{*}{$\begin{array}{c}\text { Self-closec } \\
r\end{array}$} \\
\hline & & I & II & III & & \\
\hline \multicolumn{2}{|c|}{ Regional solidarity } & & & & $-.09 * *$ & $-.24 * * *$ \\
\hline a & I often played with neighbors who were friends & .90 & -.13 & .01 & & \\
\hline $\mathrm{b}$ & I always took part in town festivals & .69 & .10 & -.01 & & \\
\hline $\mathrm{c}$ & $\begin{array}{l}\text { My family was on friendly terms with neigh- } \\
\text { boring families }\end{array}$ & .52 & .19 & -.13 & & \\
\hline d & I always exchanged greetings with neighbors & .42 & .08 & .16 & & \\
\hline e & I was often scolded by neighbors & .39 & .00 & .21 & & \\
\hline \multicolumn{2}{|c|}{ Family ties } & & & & $-.08^{*}$ & $-.23 * * *$ \\
\hline $\mathrm{f}$ & I had a lot of contact with my relatives & .08 & .74 & .02 & & \\
\hline g & Visitors often came to my home & .04 & .70 & -.02 & & \\
\hline $\mathrm{h}$ & I visited the family tomb often & -.08 & .54 & .16 & & \\
\hline $\mathrm{i}$ & Seasonal events were often hold at home & -.00 & .30 & .04 & & \\
\hline \multicolumn{2}{|c|}{ Home discipline } & & & & $-.15^{* * *}$ & $-.31 * * *$ \\
\hline $\mathrm{j}$ & I was taught manners at home & -.04 & .03 & .64 & & \\
\hline $\mathrm{k}$ & I often helped with housework & -.09 & .16 & .62 & & \\
\hline 1 & I was often scolded by my parents & .10 & -.03 & .52 & & \\
\hline $\mathrm{m}$ & I exchanged greetings with family members & .04 & .02 & .44 & & \\
\hline $\mathrm{n}$ & I have an attachment to my hometown & .26 & .07 & -.05 & $-.09 * *$ & $-.18 * * *$ \\
\hline o & I think that I talked with my parents often & .14 & -.14 & -.01 & -.06 & $-.13^{* * *}$ \\
\hline $\mathrm{p}$ & Social issues were often discussed at home & -.15 & -.08 & .06 & .03 & $-.17 * * *$ \\
\hline $\mathrm{q}$ & I could buy what I wanted & -.14 & .14 & -.39 & $.10^{* *}$ & .04 \\
\hline $\mathrm{r}$ & $\begin{array}{l}\text { When I came home from school, at least one } \\
\text { person in my family was at home }\end{array}$ & .03 & .11 & -.09 & -.05 & -.03 \\
\hline
\end{tabular}

Notes: $n=1000$ (500 men, 500 women), ${ }^{*} p<.05 .{ }^{* *} p<.01 . * * * p<.001$.

Table 3: Residential areas of participants and mean levels of Vulgarity Scale scores

\begin{tabular}{|c|c|c|c|c|c|}
\hline & & \multicolumn{2}{|c|}{ Arrogant } & \multicolumn{2}{|c|}{ Self-closed } \\
\hline & $n$ & $M$ & $S D$ & $M$ & $S D$ \\
\hline Metropolitan city & $500(50.0 \%)$ & 2.93 & 0.82 & 3.50 & 0.82 \\
\hline Medium-sized city & $300(30.0 \%)$ & 3.05 & 0.80 & 3.52 & 0.81 \\
\hline Local cities & $200(20.0 \%)$ & 3.06 & 0.73 & 3.51 & 0.83 \\
\hline Sum & $1000(100.0 \%)$ & 2.99 & 0.80 & 3.51 & 0.82 \\
\hline
\end{tabular}

no significant differences in the means of the two factors among different areas.

\subsection{Association between the vulgarity scale and social re- lationships during childhood}

Table 2 shows the correlations between the two factors that comprised the Vulgarity Scale and relationship experiences during early childhood. Both factors were negatively correlated with regional solidarity, family ties, and home discipline whereas the self-closed factor was more strongly related to the three indicators of early interactional experiences $(r=-.24$ with regional solidarity; $r=-.23$ with family ties; $r=-.31$ with home discipline; $\mathrm{p}<.001)$ than was the arrogant factor $(r=-.09$ with regional solidarity, $p<.01 ; r=-.08$ with family ties, $p<.05 ; r=$ -.15 with home discipline, $p<.001$ ).

Table 4 shows the means for the self-closed and arrogant factors among individuals with zero, one, and more than two siblings. A greater number of siblings was related to lower scores on the self-closed factor and a univariate analysis (zero siblings vs. one sibling vs. more than two siblings) revealed a main effect of the number of siblings on the self-closed factor $(F$ $(2,1000)=4.29, p=.01)$.

Taken together, these results provide evidence of the strong association between the self-closed factor and social relationships during early life. There was no clear evidence of a link between the arrogant factor and past relations, but the self- 
Table 4: Mean levels of Vulgarity Scale scores according to number of siblings

\begin{tabular}{lccccc}
\hline & \multirow{2}{*}{$n$} & \multicolumn{2}{c}{ Arrogant } & \multicolumn{2}{c}{ Self-closed } \\
\cline { 3 - 6 } & & $M$ & $S D$ & $M$ & $S D$ \\
\hline No sibling & 96 & 3.05 & 0.76 & 3.74 & 0.79 \\
\hline One sibling & 408 & 2.99 & 0.79 & 3.49 & 0.80 \\
\hline More than two siblings & 496 & 2.98 & 0.81 & 3.48 & 0.84 \\
\hline
\end{tabular}

closed factor was moderately correlated with the arrogant factor, $r=.16, p<.001$. Thus, it is possible that relationship experiences during early childhood exert an indirect influence on the development of an arrogant disposition through mitigating the development of a self-closed disposition. If this incidental hypothesis is correct, then the association between the self-closed and arrogant factors may grow stronger as individuals' age. We explored this hypothesis by calculating the correlations between the self-closed and arrogant factors according to age. The result of this analysis revealed that the correlation coefficient generally increased as age increased; $r=-.06, p>.1$ for 20-29 year olds $(n$ $=180) ; r=.13, p<.10$ for 30-39 year olds $(n=220) ; r=.29, p$ $<.001$ for 40-49 year olds $(n=188) ; r=.22, p<.001$ for $50-59$ year olds $(n=224) ; r=.26, p<.001$ for more than 60 year olds $(n=188)$. We also conducted a regression analysis in which age was regressed as a categorical predictor of the correlation coefficient. The results revealed that the age category was marginally related in a predictable manner to the dependent variable, $\beta=$ $.81, p=.09$.

\section{Discussion}

The present exploratory study of the roots of the vulgarity of the mass man provides good support for a significant link between social experiences in early life and the self-closed factor assumed in Ortega's (1932) philosophical discussions regarding the vulgarity of the masses. More specifically, the present results demonstrated that levels of regional solidarity, family ties, and home discipline exerted significant influences on the development of a self-closed personality disposition. This finding indicates that differences in vulgar dispositions are at least partially rooted in the patterns of past social relations, particularly with respect to the frequency and intimacy of interactions with family and community members. Thus, it seems likely that people raised in environments characterized by lower degrees of interdependence would be more inclined than those raised in environments characterized by a higher degree of interdependence to form self-closed dispositions.

The present study also suggested that number of siblings affects the development of a self-closed disposition. Van Lange et al. (1997) noted that having more siblings was associated with encountering situations characterized by high levels of collectivism and interdependence. In this context, the present data showing that individuals raised in larger families were less inclined to form a self-closed disposition provide additional support for the linkage between a self-closed disposition and social relationships in early life.

The present findings also revealed that there was an indirect effect of early social experiences on the development of an arrogant disposition. Supporting our hypothesis, the correlation between the self-closed and arrogant factors appeared to increase with age. Thus, an arrogant disposition may develop throughout the entire life cycle, including early adulthood and old age, especially among individuals who have already developed a selfclosed disposition. Taken together, the present results elucidate the effects of social relationships in early life by revealing that such experiences exert a direct effect on the development of a self-closed disposition and an indirect effect on the development of an arrogant disposition.

The indirect effect of social relationships may be understood in terms of the isolation of those with self-closed dispositions. That is, self-closed persons, disconnected from the outside world, may lack opportunities to compare themselves with others. As a consequence, it may be more likely that they increase their sense of hubris and self-sufficiency and go on to form an arrogant disposition. This reasoning has not yet been adequately investigated empirically but it has already been addressed by Ortega (1930/1932) in the following statement: "The innate hermetism of his soul is an obstacle to the necessary condition for his discovery of his insufficiency, namely: a comparison of himself with other beings" (p. 76).

\subsection{Implications for research and practice: How to cope} with the mass man in the context of social dilemmas

Previous research has provided empirical support for the idea that the mass man is a defector in the context of social dilemmas (Hatori et al, 2016). In light of the socially harmful impact of the mass man on social contexts, it would be important to consider the most appropriate way to reduce the detrimental effects of the mass man. The detrimental effects of the masses may not be dispelled without eliminating their vulgar disposition, which may be possible by changing "the payoff utilities that lead the players to defect," as suggested by Dawes (1980, p. 190). His proposal for eliciting cooperative behavior (e.g., communication and moralization) seems likely to be efficacious in reducing vulgar dispositions (see also Dawes, Van de Kragt \& Orbell, 1990; Kerr \& Kaufman-Gilliland, 1994). However, these measures may not be effective for those who have already developed a vulgar disposition to a considerable level because 
an arrogant person is likely to feel hostile toward prescriptive measures involving moralizing. Additionally, a self-closed person, by definition, tends to avoid communication with others. In this sense, the mass man can be regarded as a hard-core defector who rebuffs any attempts at enlisting her or his cooperation.

However, the present study offers one possibility for effectively preventing the massification of an individual; that is, the positive effects of close relationships in early life. This study provides preliminary evidence relevant to the idea that repeated experiences of close relationships prevent children from developing a vulgar personality. In particular, we found that three important factors, regional solidarity, family ties, and home discipline, appear to serve as effective buffers against the development of vulgarity. Our results suggest that different patterns of early relations have direct and indirect effects. First, it appears that close relationships during childhood were able to directly mitigate the development of a self-closed disposition. Second, past experiences with social relations may have indirect effects on preventing individuals from forming an arrogant disposition. Indeed, we found that individuals tend to develop an arrogant disposition subsequent to early childhood to the extent that they have already developed a self-closed disposition.

These findings are consistent with those of previous research on social dilemmas that have linked social relationships with behavior involving cooperation or defection. Many studies have suggested that community identification or membership enhances prosocial behavior (Brewer \& Kramer, 1986; Kramer \& Brewer, 1984, 1986) because community members generally place trust in other members (Brewer, 1981; Brewer \& Kramer, $1985)$ and/or engage in reciprocal relationships with one other (Brewer \& Kramer, 1986; Komorita, Parks, \& Hulbert, 1992). On the other hand, Twenge and colleagues (e.g., Twenge, Baumeister, DeWall, Ciarocco, \& Bartels, 2007; Twenge, Catanese, \& Baumeister, 2002) found that social exclusion leads to antisocial and misanthropic behavior such as being aggressive, self-defeating, impulsive, uncontrolled, and uncooperative. The present results add to these previous results in showing that unsatisfactory relationships in early in life facilitate the development of antisocial behavior involving defection by leading to the formation of a vulgar personality.

More generally, our findings suggest the need for more fundamental measures to eradicate the root causes of vulgar personality (i.e., by promoting stable, close social relationships). In particular, it is important to protect the integrity of the family and the solidarity of regional communities because these institutions appear to be weakening as a result of the process of modernization (Besser, 2009; Putnam, 2000). We expect that longterm and strenuous measures in this regard will yield steady effects that will reduce the defective impacts of the mass man in the long run.

\subsection{Further research}

Despite the relevance of the present findings, future research is needed to provide further insight into the psychological processes underlying the development of a vulgar personality, including different patterns of the development of self-closed and arrogant dispositions. Further analysis on the relationships between the development of vulgarity and socioeconomic variables (e.g., education and occupation) or attitudinal variables (e.g., attachment style and trust) related to childhood interaction experiences would contribute to furthering the understanding of these processes. Additionally, the present findings were based on data obtained from internet users, which is a somewhat restricted sample. Further surveys evaluating a more general sample would provide further evidence regarding the development of vulgarity.

\section{Notes}

(1) The role of social relationships has also been acknowledged in moral development theory (see Carpendale, 2000; Gibbs, Basinger, Grime, \& Snarey, 2007 for reviews). Piaget (1932/1965) assumed that children developed social and moral intelligence through managing their social interaction situations. Many studies conducted from a Piagetian perspective revealed the influence of social relation on cognitive and moral development. Kohlberg's (1969) influential theory of moral development also emphasizes the importance of social relationship in that it provides individuals with role-taking opportunities, a source of cognitive conflict (disequilibrium), which are regarded as essential for enhancing moral development.

(2) For development and validation of the Vulgarity Scale, see Hatori et al. (2016).

\section{References}

Arendt, H. (1951). The origins of totalitarianism. New York: Harcourt Brace \& World, Inc.

Besser, T. L. (2009). Changes in small town social capital and civic engagement. Journal of Rural Studies, 25, 185-193.

Brewer, M. B. (1981). Ethnocentrism and its role in interpersonal trust. In M. B. Brewer \& B. E. Collins (Eds.), Scientific inquiry and the social sciences (pp. 345-360). New York: Jossey-Bass.

Brewer, M. B. \& Kramer, R. M. (1985). The psychology of intergroup attitudes and behavior. Annual Review of Psychology, 36, 219-243.

Brewer, M. B. \& Kramer, R. M. (1986). Choice behavior in social dilemmas: Effects of social identity, group size, and decision framing. Journal of Personality and Social Psychology, 50, 543-549.

Carpendale, J. L. M. (2000). Kohlberg and Piaget on stage and moral reasoning. Developmental Review, 20, 181-205.

Dawes, R. M. (1980). Social dilemmas. Annual Review of Psy- 
chology, 31, 169-193

Dawes, R. M. \& Thaler, R. (1988). Cooperation. Journal of Economic Perspective, 2, 187-197.

Dawes, R. M., Van de Kragt, A. J. C., \& Orbell, J. M. (1990). Cooperation for the benefit of us: Not me, or my conscience. In J. Mansbridge (Ed.), Beyond self-interest (pp. 97-110). Chicago: University of Chicago Press.

Elliott, M. A. \& Merrill, F. E. (1961). Social disorganization (4th ed.). New York: Harper \& Row.

Fromm, E. (1941). Escape from freedom. New York: Henry Holt and Company.

Gibbs, J. C., Basinger, K. S., Grime, R. L., \& Snarey, J. R. (2007). Moral judgment development across cultures: Revisiting Kohlberg's universality claims. Developmental Review, 27, 443-500.

Hatori, T., Fujii, S., \& Komatsu, Y. (2016). Vulgarity of the mass man as a predictor of defection. Social Behavior and Personality, 44, 139-160.

Kagan, S. \& Knight, G. P. (1981). Social motives among AngloAmerican and Mexican-American children: Experimental and projective measures. Journal of Research in Personality, 15, 93-106.

Kelley, H. H. (1997). The "stimulus field" for interpersonal phenomena: The source of language and thought about interpersonal events. Personality and Social Psychology Review, 1, 140-169.

Kerr, N. L. \& Kaufman-Gilliland, C. M. (1994). Communication, commitment, and cooperation in social dilemmas. Journal of Personality and Social Psychology, 66, 513-529.

Kohlberg, L. (1969). Stage and sequence: The cognitive-developmental approach to socialization. In D. A. Goslin (Ed.), Handbook of socialization theory and research (pp. 347480). Chicago: Rand McNally.

Komorita, S. S., Parks, C. D., \& Hulbert, L. G. (1992). Reciprocity and the induction of cooperation in social dilemmas. Journal of Personality and Social Psychology, 62, 607-617.

Kramer, R. M. \& Brewer, M. (1984). Effects of group identity on resources use in a simulated commons dilemma. Journal of Personality and Social Psychology, 46, 1044-1057.

Kramer, R. M. \& Brewer, M. (1986). Social group identity and the emergence of cooperation in resource conservation dilemmas. In H. Wilke, D. Messick, \& C. Rutte (Eds.), Experimental studies of social dilemmas (pp. 205-234). Frankfort, Germany: Peter Lang.

Le Bon, G. (1947). The crowd: A study of the popular mind (D. Alexander, Trans.). London: Ernest Benn. (Original work published 1896)

Ledyard, J. (1995). Public goods: A survey of experimental research. In J. Kagel \& A. Roth (Eds.), Handbook of experimental economics (pp. 111-194). Princeton: Princeton University Press.

Madsen, M. C. \& Shapira, A. (1970). Cooperative and competi- tive behavior of urban Afro-American, Anglo-American, Mexican-American, and Mexican village children. Developmental Psychology, 3, 16-20.

Manheim, K. (1940). Man and society in an age of reconstruction: Studies in modern social structure (E. Shils, Trans.). London: Routledge \& Kegan Paul. (Original work published 1935)

Marwell, G. \& Ames, R. E. (1979). Experiments on the provision of public goods I: Resources, interest, group size, and the free rider problem. American Journal of Sociology, 84, 1335-1360.

Marwell, G. \& Ames, R. E. (1980). Experiments on the provision of public goods II: Provision points, stakes, experience, and the free rider problem. American Journal of Sociology, 85, 926-937.

Mlicki, M. K. (1992, July). Rationality in social dilemmas: Steady cooperators, steady defectors and compromise seekers. Paper presented at the Fifth International Conference on Social Dilemmas, Bielefeld, Germany.

Ortega, Y. G. (1932). The revolt of the masses (Anonymous, Trans. Authorized by the author). New York: W. W. Norton \& company, Inc. (Original work published 1930)

Piaget, J. (1965). The moral judgment of the child. New York: The Free Press. (Original work published 1932)

Putnam, R. D. (2000). Bowling alone: The collapse and revival of American community. New York: Simon \& Schuster.

Raley, H. C. (1971). Jose Ortega y Gasset: Philosopher of European unity. Tuscaloosa, AL: The University of Alabama Press.

Romig, C. \& Bakken, L. (1992). Intimacy development in middle adolescence: Its relationship to gender and family cohesion and adaptability. Journal of Youth and Adolescence, 21, 325-338.

Schonett-Reichl, K. A. (1999). Relations of peer acceptance, friendship adjustment, and social behavior to moral reasoning during early adolescence. Journal of Early Adolescence, 19, 249-279.

Schwartz, S. H. (1992). Universals in the content and structure of values: Theoretical advances and empirical tests in 20 countries. Advances in Experimental Social Psychology, 25, $1-65$.

Tuttle, H. N. (1996). The crowd is untruth: The existential critique of mass society in the thought of Kierkegaard, Nietzsche, Heidegger, and Ortega y Gasset. New York: Peter Lang.

Twenge, J. M., Baumeister, R. F., DeWall, C. N., Ciarocco, N. J., \& Bartels, J. M. (2007). Social exclusion decreases prosocial behavior. Journal of Personality and Social Psychology, 92, 56-66.

Twenge, J. M., Catanese, K. R., \& Baumeister, R. F. (2002). Social exclusion causes self-defeating behavior. Journal of Personality and Social Psychology, 83, 606-615. 
Van Lange, P. A. M. (1999). The pursuit of joint outcomes and equality in outcomes: An integrative model of social value orientation. Journal of Personality and Social Psychology, 77, 337-349.

Van Lange, P. A. M., Otten, W., De Bruin, E. M. N., \& Joireman, J. A. (1997). Development of prosocial, individualistic, and competitive orientations: Theory and preliminary evidence. Journal of Personality and Social Psychology, 73, 733-746.

(Received January 10, 2017; accepted February 1, 2017) 